not graduate without an active and realistic interest in the broader problems of the world to-day. The challenge is not a new one, but its urgency grows with the growing prestige of 'corporative' States. It was an outstanding motive of the remarkable series of eight university supplements published in Time and Tide in 1935. To that series Sir Ernest himself contributed an article on "Where our Universities Fail".

SIR ERnEST Simon's estimate of the responsibility of the universities in this matter is based partly on the assumption (the validity of which tends to diminish) that public opinion in Great Britain is largely determined by men and women educated at the universities, and partly on the influence the universities exert on the teaching in secondary schools through university scholarships and entrance examinations, and control over examinations in those schools. His argument finds some support in the last report of the University Grants Commissioners. But arguments must be cogent indeed to overcome the inertia of university governing bodies, especially since no provision was made for research in the social sciences when the Government of the day set up the Department of Scientific and Industrial Research. In a postscript to his paper, Sir Ernest announces that the Association for Education in Citizenship is proposing to appoint a committee on the whole problem of the universities and citizenship and invites communications from persons interested in this matter. His address is, Broom Croft, Didsbury.

\section{Public Affairs Forums in the United States}

ADULT civic education through "public affairs forums" is now being energetically pushed by the United States Federal Office of Education, the present head of which, Dr. Studebaker, played a principal part in the launching, several years ago, of the pioneer forums in Des Moines. The latest official publication on the subject, a pamphlet entitled "A Step Forward" (Superintendent of Documents, Washington, D.C. 10 cents), includes an account of ten forum demonstration centres in as many different States, managed by local educational authorities. A foreword by the Commissioner strongly emphasizes the principle of local responsibility and control, but the enterprise has been financed largely out of the Federal Emergency Relief Appropriation, and several hundred relief workers have taken part as assistant librarians, research assistants, artists, writers, accountants, typists, etc. The Secretary of the Interior, in commending the Commissioner's scheme, observes that it has brought about an essential and practical contact between "those few of our citizens who are concentrating their time and effort on the pursuit of truth in the field of social problems" and the average citizen who cannot devote much time to a specialized study of these complex questions. The success of the scheme hinges on finding competent leaders for the forums, for they have the difficult task of first presenting a topic in simple language in a way calculated to sustain interest, giving a fairly comprehensive and impartial outline of the problem and the alternative solutions, and then stimulating, leading and organizing a free discussion for forty or fifty minutes. Most of them have been obtained on leaves of absence from colleges and universities. The improvement of social intelligence for the democratic control of our material resources is, says the Commissioner, the challenge of our day.

\section{Social Services in Great Britain}

"Public Soclal Services"' (Cmd. 5310. London : H.M. Stationery Office. 4d.) portrays statistically what may, without much exaggeration, be called the social revolution of the twentieth century in Great Britain. It shows that in the first thirty years of the century the cost of the social services referred to increased just thirteen-fold, namely, from thirty-six millions to four hundred and sixty-eight millions sterling. The first decade was marked by a rise in expenditure under Education Acts from 20 to 34 millions and the coming of old age pensions which cost 7 millions in 1910. The next decade saw a leap in education expenditure from 34 to 90 millions and in old age pensions from 7 to 21 , the introduction of unemployment insurance (11 millions), national health insurance (30 millions), the mental deficiency acts, and, of course, war pensions. Between 1920 and 1930 the expenditure under unemployment insurance increased to 102 millions and under old age pensions to $37 \frac{1}{2}$ millions, and the widows', orphans' and old age contributory pensions acts came into force, involving, in 1930, an expenditure of $34 \frac{1}{2}$ millions. During this period, expenditure under the housing acts increased from $4 \frac{1}{2}$ to 40 millions.

\section{Natural History Exhibition at Wye}

The Wye College Branch of the University of London Animal Welfare Society (ULAWS) held a Natural History Exhibition at the South-Eastern Agricultural College, Wye, on March 11-13. The greater part of the Exhibition was given up to natural history specimens exemplifying the classification of the animal kingdom. Several dissections caused much interest. A fine collection of beaks and feet of birds made by a member of the Branch was on view. Specimens of bacteria, minerals and other microscopic objects were shown. In addition, there were films of animal life, including the ULAWS film on the care of dogs, which proved to be very popular. At the entrance to the Exhibition were exhibits dealing with the oil menace and the rabbit problem. The former showed how the discharged waste oil from ships and tankers floats on the surface of the sea and covers the feathers of sea-birds. Very little is enough to kill birds, causing them to die of pneu. monia due to the water being able to get at the skin. A live guillemot from which the oil had been removed was shown. In all cases so far, however, the solvent used to remove this has also removed the natural grease from the feathers, with the result that the bird gets sodden when placed in water. Further experiments are being carried out by Mr. R. S. Pitcher. A gin trap for catching rabbits was demonstrated and its unsatisfactory character explained. Instead of decreasing the animals, it often leads to an increase, 